\title{
The Determinant Factors of KAI Access Awareness in PT Kereta Api Indonesia from Millennial Generation Perspective
}

\author{
Rano Kartono $^{1 *}$; Afif Wildan Tamami ${ }^{2}$ \\ ${ }^{1,2}$ Management Department, BINUS Business School Undergraduate Program, Bina Nusantara University \\ Jl. Kebon Jeruk Raya No. 27, Kebon Jeruk, Jakarta 11530, Indonesia \\ 1'rano.kartono@binus.ac.id; ${ }^{2}$ afif.tamami@binus.ac.id
}

Received: $30^{\text {th }}$ October 2020/ Revised: $26^{\text {th }}$ November 2020/ Accepted: $07^{\text {th }}$ December 2020

How to Cite: Kartono, R. \& Tamami, A. W. (2020). The determinant factors of KAI access awareness in PT Kereta Api Indonesia from millennial generation perspective. The Winners, 21(2), 129-139.

https://doi.org/10.21512/tw.v21i2.6781

\begin{abstract}
PT Kereta Api Indonesia (Persero), as a monopoly train company in Indonesia, launches KAI Access which has been downloaded by more than 5 million users, but only about 1,1 million users are active. The research intended to determine the relationship between brand experience, brand trust, perceived quality of customer satisfaction, and brand awareness in the minds of KAI Access consumers. The research used primary data with millennial populations by 986.775 and purposive sampling method with $400 \mathrm{KAI}$ Access users spread over 9 Daops (operational areas) of PT Kereta Api Indonesia in Java with a Partial Least Square (PLS) analysis approach. The results show that brand experience and perceived quality have a positive effect on customer satisfaction while brand trust has a negative effect. Whereas customer satisfaction and brand experience are directly proportional to brand awareness.
\end{abstract}

Keywords: access awareness, Kereta Api Indonesia (KAI), millennial generation

\section{INTRODUCTION}

The development of business and the spread of information technology supported by infrastructure, especially the internet, have massively succeeded in encouraging the creation of a digital business ecosystem (e-commerce). The growth of e-commerce in Indonesia is the fastest in the world in 2018 by $78 \%$ where the average Indonesian people spend Rp. 3,19 million per person or US\$ 228 per person (Widowati, 2019). To carry out business continuity in the e-commerce era, PT Kereta Api Indonesia (Persero) has launched the KAI Access application with ticket booking features for local, medium, and distant railway, airport trains, e-boarding pass, rescheduling, cancellations, refunds, and pre-order meals that can be accessed by users for 24 hours with various payment method options-ATM/mobile banking/internet banking, Debit/credit, Minimarket and Link e-wallet ("KAI Access train booking", 2019).

However, with the complete features offered by KAI Access, it has not yet become an option for users to meet the needs of traveling by train. The data states that on average, this application has been downloaded around 5 million people but active users only range between 1,1 million. In general, KAI Access application in play store gets a star rating of 2,8 out of the total 5 stars available. Meanwhile, Traveloka application competitor becomes top of mind with 4,5 stars and more than 10 million downloaders ("KAI Access train booking", 2019). This raises gap on why this application is not entirely used or not chosen by the downloaders. Cordasco (2016) points out four reasons why intended users do not access the application, which are: 1) the application does not provide enough value for its users; 2) problematic application (bug), slow or cannot be used optimally; 3 ) the application is difficult to operate and confusing; 4) the application is no better than competitors.

The experience of using the application will establish the value of whether a brand will provide satisfaction which ultimately determines the possibility of being used. The decision to use an application is also determined by the user's view of the application's perceived quality. High quality is believed to increase customers' satisfaction which makes them repurchase (Saleem et al., 2015). The application must be trustworthy, reliable, and credible because the application requires user personal information which is 
highly prone to be misused and traded by irresponsible people (Setyawan, Kussdiyarsana, \& Imronudin 2015). Components of brand experience, perceived quality, and brand trust will encourage customers to assess the extent to which the application product is able to provide customer satisfaction. Customer satisfaction is expected to be able to shape consumers' mindset and purchase behavior so that brand awareness is formed. As a result, repurchase can occur since customers trust its quality (Bilgili and Ozkul, 2015).

The low rating of the KAI Access application on the play store and large gap of the downloaders with active users show that there is a problem on why this application is not the option for ticket transaction despite being developed by state-owned company (BUMN) as the sole operator of train management in Indonesia. This large gap indicates that customer satisfaction from using KAI Access cannot be achieved so that the level of brand awareness is considered low. Therefore, the research aims to determine the level of customer satisfaction from three variables - brand experience, perceived quality, and brand trust- to find out the most dominant variable in determining customer satisfaction. Meanwhile, brand awareness variable is measured by brand experience and customer satisfaction variables to investigate the most essential variable in increasing brand awareness.

Brand is an attribute (name, term, sign, symbol, or combination) to identify a product and distinguish it from competitors that can create value and influence in the market (Kotler \& Kevin, 2005). According to Brakus et al. (2009) brand experience is the result of brand stimulation by involving four dimensions, namely: 1) sensory (the brand can make consumers amazed and feel interested); 2) affective (brand influences a person's attitude (potential consumers) to an object or phenomenon); 3) behavioral (brand is related to motor behavior and behavioral experience which brands can create through product design and identity, packaging, communication, and the environment); and 4) intellectual (brand influences the ability to think and solve problems cognitively by using intellectual concepts).

Perceived quality is consumers' perception towards the overall quality and excellence of a product or service that actually meet consumers' expectations (Aaker, 1991). According to Durianto et al (2001), there are five values in describing the perceived quality, namely: 1) reasons to buy/consume; 2) product differentiation/position; 3) optimum price; 4) interest in distribution channels; and 5) brand expansion. According to Acebrón and Dopico (2004), measurement of quality in terms of marketing must use an intrinsic point of view where assessment relates to the physical characteristics inherent in the product, and extrinsic element where assessment of consumers' assessment is based on others'.

Brand trust is a secure feeling that consumers have as a result of interaction with a brand based on the perception that the brand is reliable and responsible for the interests and safe for consumers
(Lin \& Wang, 2006). Brand trust is measured by using two approaches namely brand reliability-the brand meets the promised value or meets the expectations of consumers, and brand intention - assessment based on consumer belief that the brand prioritizes the interests of consumers if unexpected problems arise (Firmansyah, 2019).

Customer satisfaction can be interpreted as the result of a subjective assessment of consumers when the selected brands can meet or exceed the expectations (Engel et al, 2010). The quality of a relationship with a brand can be seen from how consumers perceive the brand as a partner capable of providing satisfaction when or after consuming a brand. When product performance is much lower than expectations, consumers are not satisfied. When performance is in line with or exceeds expectations, consumers are satisfied. According to Irawan (2012), satisfaction is the perception of products or services that have met expectations.

Brand awareness is the ability of consumers to remember a brand and its distinction when compared to other brands. According to East (1997), brand awareness is recognition and remembrance of a brand and differentiation from other brands in the field. There are four levels of brand awareness, namely: 1) unaware of the brand; 2) brand recognition; 3 ) brand recall; and 4) top of mind.

According to Parry and Urwin (2011), generation grouping is based on two factors, namely demographic factors, in particular, the similarity of birth years, and sociological factors related to the history and special events that are simultaneously experienced. According to Howe and Straus (2000), there are three attributes that clearly describe the generation grouping compared to the year of birth, namely: 1) perceived membership (individual perceptions of the groups to which they are); 2) common beliefs and behavior (attitudes towards life, career, politics, and religion); c) common location in history (explaining changes in views and events). In general, the generation grouping is divided into: 1) veterans $(<1946)$; 2) baby boomers (19461960); 3) generation $X(1961-1980)$; 4) generation $Y /$ millennial (1981-2000); and 5) generation Z (20012010). Generation $Y$ (millennial) is a generation where technology has developed (internet booming) such as email, short message service (SMS), and social media. According to Badan Pusat Statistik (2019), the level of consumption in the millennial generation depends on the use of internet data and supporting devices reaching $91,62 \%$ or 4,43 billion users from the previous generation which is only by $43,72 \%$. Characteristics that stick to the millennial generation does not see the brand as the main thing. Instead, they like challenges and refer to the addition of experience to enrich life. This generation is very enthusiastic in exploring tourism wealth and originality or uniqueness of new places that they have never visited to become a social media content ("Milenial lebih prioritaskan", 2017).

According to Agata et al. (2017), brand 
experience is the result of consumers' subjective assessment towards a brand that is able to exceed the consumers' expectations and provide satisfaction. Baser et al. (2016) state that brand experience has a positive effect and significant results on customer satisfaction in the research on game brands and consumers goods. In a certain time, the correlation between user experiences is directly proportional to customer satisfaction. Sidabutar and Diah (2015) point out that brand experience has a significant effect on customer satisfaction. When consumers' need is fulfilled, satisfaction will increase.

\section{$H_{l}:$ Brand Experience has a positive effect on customer} satisfaction.

According to Souki and Filho (2008), customer satisfaction is determined by three factors, namely perceived quality, perceived value, and expectation. If customers assess the brand performance is equal to or better than expectations, there is a tendency that customers will be satisfied. Spais and Vasileiou (2006) state that perceived quality is consumers' perception towards the overall quality and superiority of products and services according to the intended purpose based on comparison with the costs incurred to obtain and use the product. Saleem et al (2015) shows that the better consumers' perception of quality will tend to shape consumer satisfaction to consume the product in the future.

\section{$H_{2}$ : Perceived quality has a positive effect on the satisfaction.}

Lin and Wang (2006) state that trust has been identified as a key factor in e-commerce that tends to have a strong impact on customer purchasing decisions. Liao et al. (2015) state that there is a significant positive relationship between brand trust and customer satisfaction in which consumers feel confident to consume a brand. In the minds of consumers, the brand will provide satisfaction, especially if consumers like the brand. Saputra and Dewi (2016) have pointed out that if consumers trust a brand, it is likely to form positive behavior towards the brand, especially if consumers have good experience with the brand.

\section{$H_{3}$ : Brand trust has a positive effect on customer satisfaction.}

Saleem et al. (2015) state that the satisfaction is established by the experience of repeated use of products and services providing good memories and mindset on consumers to recognize or recall that a brand is part of certain product categories. Nair (2013) point out that brand awareness refers to product associations that arise in the minds of customers after repeated exposure to products through advertising. Customer satisfaction is built when customers have trust in the brand. Bilgili and Ozkul (2015) state that business communication is necessary to have brand awareness to establish brand identity and brand strength itself. There is a strong relationship between customer satisfaction and brand awareness since good marketing communication is required to dominate the market and to form customer satisfaction and prove that the brand is easy to remember later on.

$H_{4}$ : customer satisfaction has a positive effect on brand awareness.

Cleff, Lin, and Walter (2014) view brand experience to form experiences that stimulate the five senses to play an important role in shaping brand awareness in the minds of consumers. Baumann et al. (2015) state that consumers can remember brands that have experience in personally using for durable goods while for fast-moving consumer goods (FMCG), it is easier for consumers to remember due to the high marketing intensity. Xixiang et al. (2016) show that the relationship between brand experience and brand awareness has a significant positive relationship in a research on smartphone brands in China. The experience of using a brand will produce memories in consumers' minds that produce strong and unique stimulus in memory. Brand experience has an important role to have distinguished aspects from competing products, as well as to form a positive brand image resulting in a strong brand association.

$H_{5}$ : Brand experience has a positive effect on brand awareness.

Based on the previous research, the developing hypothesis study model is presented in Figure 1.

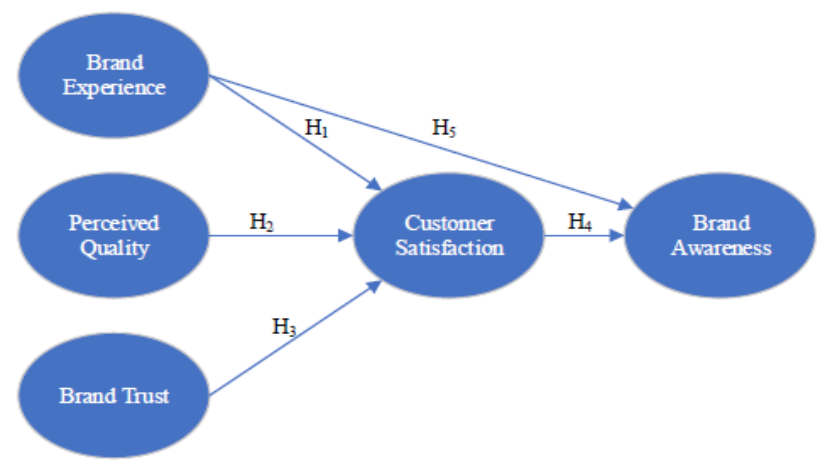

Figure 1 Developing Hypothesis Study Model

\section{METHODS}

The population in the research are all age groups included in the millennial generation, i.e., people born in 1981 to 2000 (age groups 21 to 40 years old). Based on primary data, the total population of active users of KAI Access from the millennial generation is 986.775 , so with the Slovin formula approach, the minimum sample of 400 respondents spread across nine Operating Areas of PT KAI (Persero) on Java 
island. Data are collected from $10^{\text {th }}$ December 2019 to $25^{\text {th }}$ February 2020, in which peak passenger periods occurs during the transportation of Christmas 2019 and New Year 2020. For instance, from $15^{\text {th }}$ December 2019 to $10^{\text {th }}$ January 2020, and after the transportation period of Christmas to New Year, the number of passengers served begins to decline to normal. Data are taken by collecting data in the form of a Linkert scale questionnaire which is transferred to the Google form, then the link will be distributed to the respondents. Respondents are selected based on two criteria, namely: 1) respondents who are selected based on the millennial age group based on ID Card (Kartu Tanda Penduduk) or Temporary Stay Permit Card (Kartu Izin Tinggal Terbatas) used when boarding (company regulations require boarding passengers at the station to show a valid KTP); 2) respondents who get on board using an e-boarding pass (this feature is only available in the KAI Access application).

The research takes the object of the KAI Access application developed by PT Kereta Api Indonesia (Persero). The KAI Access features are examined only for users of first-class inter-city trains (local, medium, and distant trains) operated by PT Kereta Api Indonesia (Persero), not included in the KAI Commuter Jabodetabek passengers operated by PT
Kereta Commuter Indonesia (KCI) Jabodetabek and Airport Railway (PT Railink). The research also takes respondents data from local railways which are only sold at KAI Access and not traded for other applications. The respondents involved are the millennial generation (born in 1981 to early 2000) who have had experience using the KAI Access features at least once. Respondents are passengers who have used the KAI Access application and carried out boarding with e-boarding pass.

The operational definition of a variable is the concept of a measurable variable which can be observed through its dimensions, certain aspects or attributes attached to a concept (Sekaran \& Bougie, 2010). Exogenous (independent) variables have values that are not influenced by other variables in the model. In the research, the exogenous variables are brand experience, brand trust, and perceived quality. Endogenous (dependent) variables have values that is influenced and determined by other variables in the model. In this research, the dependent variables are customer satisfaction and brand awareness. All variables are analyzed with the indicators which have been tested from several previous research. All variables and indicators are shown in Table 1.

The validity test is the degree of consistency

Table 1 Study Variable Indicators

\begin{tabular}{|c|c|c|c|}
\hline Variable & Item & Indicator & Source \\
\hline \multirow[t]{7}{*}{ Brand experience } & BE1 & $\begin{array}{l}\text { KAI Access provides the cheapest ticket price than other } \\
\text { similar applications. }\end{array}$ & $\begin{array}{l}\text { Larasati et al. (2018) } \\
\text { Agata et al. (2017) }\end{array}$ \\
\hline & BE2 & $\begin{array}{l}\text { KAI Access provides the most interesting promo/discount/ } \\
\text { point member/other rewards than other similar apps }\end{array}$ & \\
\hline & BE3 & $\begin{array}{l}\text { KAI Access provides convenience experience in choosing } \\
\text { schedule, reschedule and departure cancellation of } \\
\text { prospective passengers }\end{array}$ & \\
\hline & BE4 & $\begin{array}{l}\text { KAI Access can be used in all types of mobile system } \\
\text { smartphone without failure (Android, IOS and other OS) }\end{array}$ & \\
\hline & BE5 & $\begin{array}{l}\text { KAI Access provides information about the most updated } \\
\text { seat availability and feature option of supporting integrated } \\
\text { transportation services }\end{array}$ & \\
\hline & BE6 & $\begin{array}{l}\text { KAI Access provides various payment method options for } \\
\text { prospective passengers }\end{array}$ & \\
\hline & BE7 & Overall, using KAI Access is a fun and impressed thing & \\
\hline \multirow[t]{5}{*}{ Perceived quality } & PE1 & $\begin{array}{l}\text { KAI Access has an important and prominent feature that } \\
\text { similar apps don't have (ex: Location, E boarding Pass) }\end{array}$ & $\begin{array}{l}\text { Saleem (2015) \& } \\
\text { Larasati et al. (2018) }\end{array}$ \\
\hline & PE2 & $\begin{array}{l}\text { KAI Access provides the most accurate information about } \\
\text { changes to train schedules and information related to } \\
\text { railways in Indonesia }\end{array}$ & \\
\hline & PE3 & $\begin{array}{l}\text { KAI Access can be accessed in all internet network } \\
\text { conditions (ex: at least } 3 \mathrm{G} \text { network) }\end{array}$ & \\
\hline & PE4 & $\begin{array}{l}\text { KAI Access provides cancellation and refund to } \\
\text { prospective passenger features which are connected to the } \\
\text { passenger Bank account }\end{array}$ & \\
\hline & PE5 & $\begin{array}{l}\text { Refund and payment failure with non-cash in KAI Access } \\
\text { is always done quickly and on time }\end{array}$ & \\
\hline
\end{tabular}


Table 1 Study Variable Indicators (Continued)

\begin{tabular}{|c|c|c|c|}
\hline Variable & Item & Indicator & Source \\
\hline \multirow{9}{*}{ Brand trust } & PE6 & $\begin{array}{l}\text { KAI Access provides better After-Sales Services than } \\
\text { similar apps (e-chat, email \& CS) }\end{array}$ & \\
\hline & PE7 & $\begin{array}{l}\text { Overall, KAI Access is the most superior application for } \\
\text { booking train ticket among similar apps }\end{array}$ & \\
\hline & BT1 & $\begin{array}{l}\text { KAI Access is reliable and credible because the application } \\
\text { developed and operated by transportation state-owned } \\
\text { company (BUMN) of PT Kereta Api Indonesia (Persero) }\end{array}$ & $\begin{array}{l}\text { Ardyan et al. (2016) \& } \\
\text { Chinomona (2013) }\end{array}$ \\
\hline & BT2 & $\begin{array}{l}\text { KAI Access is relied on not to queue and priority service } \\
\text { of E boarding pass when boarding at the station }\end{array}$ & \\
\hline & BT3 & $\begin{array}{l}\text { KAI Access is relied on in changing registered account } \\
\text { data and updating the latest customer information }\end{array}$ & \\
\hline & BT4 & $\begin{array}{l}\text { KAI Access is reliable if there are a failure and fraud } \\
\text { system that result in losses to prospective passengers (ex., } \\
\text { Double Seat, error android system) }\end{array}$ & \\
\hline & BT5 & $\begin{array}{l}\text { KAI Access is relied on in storing and limiting the } \\
\text { dissemination of passenger's personal information }\end{array}$ & \\
\hline & BT6 & $\begin{array}{l}\text { KAI Access is reliable and secure in payment method } \\
\text { choosing and fraud in the payment system }\end{array}$ & \\
\hline & BT7 & $\begin{array}{l}\text { Overall, KAI Access is reliable and I believe in its use } \\
\text { because of its reliability and safety }\end{array}$ & \\
\hline \multirow[t]{7}{*}{$\begin{array}{l}\text { Customer } \\
\text { satisfaction }\end{array}$} & $\mathrm{CS} 1$ & $\begin{array}{l}\text { KAI Access provides satisfaction in the ease of booking, } \\
\text { rescheduling, and cancellation of train tickets }\end{array}$ & $\begin{array}{l}\text { Carrizo-Moreira et al. } \\
\text { (2016); Ardyan et al. }\end{array}$ \\
\hline & $\mathrm{CS} 2$ & $\begin{array}{l}\text { KAI Access provides satisfaction in terms of price and } \\
\text { promo that are more profitable for customers }\end{array}$ & (2016) \\
\hline & $\mathrm{CS} 3$ & $\begin{array}{l}\text { KAI Access provides satisfaction due to the simple, easy- } \\
\text { to-use, and straightforward system }\end{array}$ & \\
\hline & CS4 & $\begin{array}{l}\text { KAI Access provides satisfaction in choosing the payment } \\
\text { method needed and owned by the customer }\end{array}$ & \\
\hline & CS5 & $\begin{array}{l}\text { KAI Access provides satisfaction because it is connected } \\
\text { to the integrated transportation supporting method }\end{array}$ & \\
\hline & CS6 & $\begin{array}{l}\text { KAI Access provides satisfaction because of quick } \\
\text { feedback when customers experience interferes through } \\
\text { electronic media (e-Chat, KAI 121, email, SMS dsb) }\end{array}$ & \\
\hline & CS7 & $\begin{array}{l}\text { Overall, KAI Access provides satisfaction in its use and } \\
\text { makes it easier for prospective passengers to use it }\end{array}$ & \\
\hline \multirow[t]{7}{*}{ Brand awareness } & BA1 & $\begin{array}{l}\text { KAI Access is an app developed by PT Kereta Api } \\
\text { Indonesia (Persero) }\end{array}$ & $\begin{array}{l}\text { Chinomona (2013) \& } \\
\text { Ardyan et al. (2016) }\end{array}$ \\
\hline & BA2 & $\begin{array}{l}\text { When traveling by train, the option of purchasing tickets } \\
\text { is always at KAI Access }\end{array}$ & \\
\hline & BA3 & $\begin{array}{l}\text { When there is a train logo which is dominated by blue and } \\
\text { orange colors, you will be reminded of KAI Access }\end{array}$ & \\
\hline & BA4 & $\begin{array}{l}\text { The cheapest train ticket price, QR code in the train is only } \\
\text { in KAI Access app }\end{array}$ & \\
\hline & BA5 & $\begin{array}{l}\text { E-boarding pass and Location Features are the forms of } \\
\text { the association from the reminder to KAI Access app }\end{array}$ & \\
\hline & BA6 & $\begin{array}{l}\text { Tag Lines "selalu ada jalan" and "pesen tiket kereta } \\
\text { semudah update status" are KAI Access taglines }\end{array}$ & \\
\hline & BA7 & $\begin{array}{l}\text { Overall, KAI Access is the most complete and easy-to- } \\
\text { remember app for booking the train ticket }\end{array}$ & \\
\hline
\end{tabular}

Source: Author (2020) 
between the data used in the research of a measuring instrument that is said to be valid if the statements can show what is being measured (Sugiyono, 2008). The criteria that must be met are the total score through the Pearson Correlation technique (product moment) with the criteria for the validity coefficient (riT) $\geq$ table correlation (rtable) means that the item is declared valid. The reliability test is an instrument to test and measure the degree of confidence of a measuring instrument using the Cronbach's Alpha value approach. The criteria that must be met is if the Cronbach's Alpha value is $>0,5$. PLS analysis is an analysis that can be used to find a relationship between two or more variables, consisting of exogenous and endogenous variables.

a. Relationship between variable of brand experience, brand trust and perceived quality with customer satisfaction.

$$
Y=b_{1} X_{1}+b_{2} X_{2}+b_{3} X_{3}
$$

In which:

$$
\begin{array}{ll}
\mathrm{Y} & =\text { customer satisfaction } \\
\mathrm{b}_{1}, \mathrm{~b}_{2}, \ldots & =\text { variable coefficient } \\
\mathrm{X}_{1} & =\text { brand experience } \\
\mathrm{X}_{2} & =\text { perceived quality } \\
\mathrm{X}_{3} & =\text { brand trust }
\end{array}
$$

b. Relationship between customer satisfaction and brand experience with brand awareness.

$$
Y=b_{1} X_{1}+b_{2} X_{2}
$$

In which:

$$
\begin{array}{ll}
\mathrm{Y} & =\text { brand awarenes } \\
\mathrm{b}_{1}, \mathrm{~b}_{2}, \ldots & =\text { variable coefficient } \\
\mathrm{X}_{1} & =\text { customer satisfaction } \\
\mathrm{X}_{1} & =\text { brand experience }
\end{array}
$$

The t-test is carried out to test the coefficients on exogenous variables against endogenous variables directly (Ghozali, 2013). The results of the early t-test will be compared with the $t$ table using a significant level of $5 \%$, in which the hypothesis is accepted if the value $\mathrm{t} \leq \mathrm{t}_{\text {table }}$ and rejected if the value $\mathrm{t} \geq \mathrm{t}_{\text {table }}$.

\section{RESULTS AND DISCUSSIONS}

Retrieval of data focuses on respondents who carries out departure boarding at the initial station where respondents have used e-boarding passes and showed ID card or valid identity. The results of the characteristics of respondents are divided as seen in Table 2.

Table 2 shows that $52,8 \%$ respondents are male whose age range is $26-30$ years at 32,8 in Daop 6 Yogyakarta, where this place is an educational and tourist destination. Calculation of the validity evaluates the validity of the reflective model by considering the value of the loading factor. If the loading factor value is above 0,6 (loading factor $>0,6$ ), the instrument meets the convergent validity test (see Table 3).

Table 2 Characteristics of Study Respondents

\begin{tabular}{llcc}
\hline Description & \multicolumn{1}{c}{ Groups } & Qty. & \% \\
\hline Gender & Male & 211 & 52,8 \\
Age & Female & 189 & 47,3 \\
& 21-25 Years Old & 103 & 25,8 \\
& 26-30 Years Old & 131 & 32,8 \\
& 31-35 Years Old & 116 & 29,0 \\
Location & 36-40 Years Old & 50 & 12,5 \\
& Daop 1 Jakarta & 60 & 15 \\
& Daop 2 Bandung & 45 & 11,3 \\
& Daop 3 Cirebon & 45 & 11,3 \\
& Daop 4 Semarang & 45 & 11,3 \\
& Daop 5 Purwokerto & 30 & 7,5 \\
& Daop 6 Yogyakarta & 75 & 18,8 \\
& Daop 7 Madiun & 30 & 7,5 \\
& Daop 8 Surabaya & 55 & 13,8 \\
& Daop 9 Jember & 15 & 3,8 \\
\hline
\end{tabular}

Source: Author Data Process (2020)

An instrument is said to meet the convergent validity test if it has an Average Variance Extracted (AVE) above 0,5 . Based on Table 4 , it can be seen that the variables of brand experience, perceived quality, brand trust, customer satisfaction, and brand awareness produce the value of Average Variance Extracted (AVE) greater than 0,5. Thus, indicators that measure brand experience, perceived quality, brand trust, customer satisfaction, and brand awareness variables are declared valid.

Test criteria state that if composite reliability is greater than 0,7 and Cronbach's alpha value is greater than 0,6 , so the construct is declared reliable. Table 5 shows that the value of composite reliability on the variable of brand experience, perceived quality, brand trust, customer satisfaction, and brand awareness is greater than 0,7 . Thus, based on the calculation of composite reliability of all indicators that measure the variable of brand experience, perceived quality, brand trust, customer satisfaction, and brand awareness are declared reliable.

Testing the direct influence hypothesis is used to test whether there is an effect of exogenous variables directly on endogenous variables. The test criteria state that if the path coefficient is positive and the value of T-statistics $\geq$ T-table $(1,645)$ then it is stated that there is a positive and significant influence of exogenous variables on endogenous variables. The results of hypothesis testing is provided in Table 6 . 
Table 3 Table of Convergent Validity Test Result

\begin{tabular}{|c|c|c|c|c|c|}
\hline Variable & Item & Mean & $\begin{array}{c}\text { Loading } \\
\text { F. }\end{array}$ & $\begin{array}{c}\text { S. } \\
\text { Error }\end{array}$ & $\begin{array}{c}T \\
\text { Stat }\end{array}$ \\
\hline \multirow{7}{*}{$\begin{array}{l}\text { Brand } \\
\text { experience }\end{array}$} & BE1 & 3,11 & 0,901 & 0,016 & 56,329 \\
\hline & BE2 & 2,81 & 0,903 & 0,012 & 75,996 \\
\hline & BE3 & 4,19 & 0,950 & 0,008 & 114,54 \\
\hline & BE4 & 3,94 & 0,857 & 0,024 & 36,064 \\
\hline & BE5 & 4,29 & 0,965 & 0,005 & 199,30 \\
\hline & BE6 & 4,41 & 0,918 & 0,013 & 68,686 \\
\hline & BE7 & 4,13 & 0,900 & 0,021 & 43,567 \\
\hline \multirow{7}{*}{$\begin{array}{l}\text { Perceived } \\
\text { quality }\end{array}$} & PE1 & 3,90 & 0,753 & 0,059 & 12,743 \\
\hline & PE2 & 3,56 & 0,631 & 0,058 & 10,858 \\
\hline & PE3 & 3,39 & 0,949 & 0,012 & 79,422 \\
\hline & PE4 & 3,57 & 0,831 & 0,024 & 34,935 \\
\hline & PE5 & 3,22 & 0,918 & 0,012 & 77,464 \\
\hline & PE6 & 3,30 & 0,915 & 0,014 & 64,543 \\
\hline & PE7 & 3,49 & 0,913 & 0,017 & 52,438 \\
\hline \multirow[t]{7}{*}{ Brand trust } & BT1 & 4,34 & 0,928 & 0,010 & 94,726 \\
\hline & BT2 & 4,46 & 0,901 & 0,015 & 58,268 \\
\hline & BT3 & 3,93 & 0,759 & 0,049 & 15,516 \\
\hline & BT4 & 3,29 & 0,769 & 0,052 & 14,831 \\
\hline & BT5 & 3,21 & 0,815 & 0,036 & 22,760 \\
\hline & BT6 & 4,10 & 0,801 & 0,029 & 27,358 \\
\hline & BT7 & 3,10 & 0,909 & 0,011 & 80,279 \\
\hline \multirow{7}{*}{$\begin{array}{l}\text { Customer } \\
\text { satisfaction }\end{array}$} & CS1 & 4,31 & 0,937 & 0,012 & 76,658 \\
\hline & $\mathrm{CS} 2$ & 2,81 & 0,803 & 0,020 & 40,372 \\
\hline & $\mathrm{CS} 3$ & 2,91 & 0,853 & 0,019 & 45,846 \\
\hline & CS4 & 3,15 & 0,703 & 0,056 & 12,553 \\
\hline & CS5 & 3,81 & 0,800 & 0,037 & 21,619 \\
\hline & CS6 & 4,22 & 0,789 & 0,046 & 17,249 \\
\hline & CS7 & 3,51 & 0,738 & 0,063 & 11,622 \\
\hline \multirow{7}{*}{$\begin{array}{l}\text { Brand } \\
\text { awareness }\end{array}$} & BA1 & 4,48 & 0,796 & 0,030 & 26,238 \\
\hline & $\mathrm{BA} 2$ & 3,10 & 0,835 & 0,027 & 31,169 \\
\hline & BA3 & 2,92 & 0,864 & 0,021 & 41,936 \\
\hline & BA4 & 3,20 & 0,606 & 0,070 & 8,686 \\
\hline & BA5 & 3,47 & 0,738 & 0,048 & 15,447 \\
\hline & BA6 & 3,34 & 0,788 & 0,047 & 16,681 \\
\hline & BA7 & 3,43 & 0,762 & 0,046 & 16,696 \\
\hline
\end{tabular}

Source: Author Data Process (2020)

Table 4 Table of Validity Test Results of Convergent with AVE

\begin{tabular}{lc}
\hline \multicolumn{1}{c}{ Variable } & $\begin{array}{c}\text { Average Variance } \\
\text { Extracted }\end{array}$ \\
\hline Brand experience & 0,599 \\
Perceived quality & 0,836 \\
Brand trust & 0,711 \\
Customer satisfaction & 0,650 \\
Brand awareness & 0,724 \\
\hline
\end{tabular}

Source: Author Data Process (2020)
Table 5 Table of Reliability Test Result of Construct

\begin{tabular}{lcc}
\hline \multicolumn{1}{c}{ Variable } & $\begin{array}{c}\text { Composite } \\
\text { Reliability }\end{array}$ & $\begin{array}{c}\text { Cronbach's } \\
\text { Alpha }\end{array}$ \\
\hline Brand experience & 0,912 & 0,886 \\
Perceived quality & 0,973 & 0,967 \\
Brand trust & 0,945 & 0,932 \\
Customer satisfaction & 0,928 & 0,909 \\
Brand awareness & 0,948 & 0,934 \\
\hline
\end{tabular}

Source: Author Data Process (2020)

Table 6 Table of Direct Hypothesis Test Result

\begin{tabular}{|c|c|c|c|c|}
\hline $\begin{array}{c}\text { Hypoth- } \\
\text { esis }\end{array}$ & Variable & $\begin{array}{c}\text { T- } \\
\text { Stat }\end{array}$ & T-Tab & Remark \\
\hline $\mathrm{H}_{1}$ & $\begin{array}{l}\text { Brand ex- } \\
\text { perience } \rightarrow \\
\text { Customer } \\
\text { satisfaction }\end{array}$ & 8,538 & 1,645 & Accepted \\
\hline $\mathrm{H}_{2}$ & $\begin{array}{l}\text { Perceived } \\
\text { quality } \rightarrow \\
\text { Customer } \\
\text { satisfaction }\end{array}$ & 1,836 & 1,645 & Accepted \\
\hline $\mathrm{H}_{3}$ & $\begin{array}{l}\text { Brand trust } \\
\rightarrow \text { Customer } \\
\text { satisfaction }\end{array}$ & 0,441 & 1,645 & Rejected \\
\hline $\mathrm{H}_{4}$ & $\begin{array}{l}\text { Customer } \\
\text { satisfaction } \\
\rightarrow \text { Brand } \\
\text { awareness }\end{array}$ & 5,195 & 1,645 & Accepted \\
\hline $\mathrm{H}_{5}$ & $\begin{array}{l}\text { Brand } \\
\text { experience } \\
\rightarrow \text { Brand } \\
\text { awareness }\end{array}$ & 2,926 & 1,645 & Accepted \\
\hline
\end{tabular}

Source: Author Data Process (2020)

The first hypothesis about the effect of brand experience on customer satisfaction is accepted, meaning that the brand experience variable has a positive effect on customer satisfaction. This reinforces Agata et al. (2017) which state that the experience of using a brand at the beginning of the use will form the perception of customer satisfaction. Satisfied customers have tendencies to repurchase the same brand. In contrast, unsatisfied customers are most likely not going to trust the brand anymore.

The second hypothesis shows that perceived quality has a positive effect on customer satisfaction. This is in agreement with Saleem et al. (2015) which show that customer perception of brands is very influential on customer satisfaction. In customer perception, the brand must have advantages and quality following the comparison of costs to be incurred by the customer. Thus, the higher perceived quality tends 
to establish customer satisfaction and encourage them to repurchase in the future.

The third hypothesis about brand trust has a positive effect on customer satisfaction in the research is rejected. This is consistent with Minta (2018) which states that brand trust has negative effects on customer satisfaction in the insurance service industry. This is inversely proportional to the statement by Kiyani et al. (2012) that in the automotive industry in Pakistan, brand trust has a significant effect on customer satisfaction and brand loyalty. Brand trust is basically an emotional commitment of customers to the brand. The research also shows that trust has an important role in determining purchasing decisions by customers repeatedly and forming customer satisfaction in the long run.

In the research, brand trust does not significantly influence customer satisfaction. This reinforces the data that the number of KAI Access downloaders through the Playstore is more than 5 million downloaders but only $20 \%$ of them are active users are only around 1,1 million people, there is still a high gap range. This is an indication that KAI Access is widely downloaded by the millennial generations. However, since there is lack of customers' trust in this application, customers' satisfaction tends to be low, which ends up with the fact that the application is not used and removed from the smartphones.

The fourth hypothesis is accepted, where the influence of customer Satisfaction on brand awareness is directly proportional. This is in accordance with the theory of East (1997) which states that brand awareness is the ability of consumers to remember a brand and make it different from other similar brands with a difference of four levels, namely unaware of the brand, brand recognition, brand recall and top of mind. It means that higher level of customer satisfaction will affect consumers' memories to remember the brand.

The fifth hypothesis is accepted, where brand experience is directly proportional to brand awareness. This follows Cleff et al. (2014) pointing out that the experience of using a brand will stimulate the five senses to play an important role in consumers' minds so that it is easy to remember, which form an unconscious awareness to determine future brand consumption.

Goodness of fit model in analysis of PLS is conducted by using R-squared. The result of goodness of fit model has been summarized in Table 7. Customer satisfaction variable $\mathrm{R}$-squared has a value of $0,896(89,6 \%)$ showing that the diversity of customer satisfaction variable can be explained by the variable of brand experience, perceived quality, and brand trust by $89,6 \%$, while the remaining $10,4 \%$ contributed by other variables is not discussed in the research. R-squared of brand awareness variable is $0,920(92,0 \%)$ showing that the diversity of brand awareness variable can be explained by the variable of brand experience and customer satisfaction by $92,0 \%$ while the remaining $8,0 \%$ contributed by other variables is not discussed.
Table 7 Table of Goodness of fit Model Test Result

\begin{tabular}{lc}
\hline \multicolumn{1}{c}{ Endogenous Variable } & R-Squared \\
\hline Customer satisfaction & 0,896 \\
Brand awareness & 0,920 \\
\hline
\end{tabular}

Source: Author Data Process (2020)

The conversion of the path diagram in the measurement model is intended to determine the effect directly or indirectly. The direct and indirect effects of the model are presented in Table 8 and Table 9.

Table 8 Diagram Conversion Result Path 1

\begin{tabular}{|c|c|c|}
\hline Exogenous & Endogenous & $\begin{array}{c}\text { Direct } \\
\text { Coefficients }\end{array}$ \\
\hline Brand experience & $\begin{array}{l}\text { Customer } \\
\text { satisfaction }\end{array}$ & $0,963^{*}$ \\
\hline Perceived quality & $\begin{array}{l}\text { Customer } \\
\text { satisfaction }\end{array}$ & $0,087^{*}$ \\
\hline Brand trust & $\begin{array}{l}\text { Customer } \\
\text { satisfaction }\end{array}$ & $-0,060$ \\
\hline
\end{tabular}

Remark: * (Significant)

Source: Author Data Process (2020)

Table 8 and Table 9 show the measurement model for the variable $\mathrm{Y}$ (customer satisfaction) and variable $X_{1}$ (brand experience), $X_{2}$ (perceived quality) and $X_{3}$ (brand trust), which is:

$\mathrm{Eq} 1: \mathrm{CS}=0,963 \mathrm{BE}+0,087 \mathrm{PE}-0,060 \mathrm{BT}$

Table 9 Diagram Conversion Result Path 2

\begin{tabular}{llc}
\hline \multicolumn{1}{c}{ Exogenous } & Endogenous & $\begin{array}{c}\text { Direct } \\
\text { Coefficients }\end{array}$ \\
\hline Brand experience & Brand awareness & $0,348^{*}$ \\
$\begin{array}{l}\text { Customer } \\
\text { satisfaction }\end{array}$ & Brand awareness & $0,608^{*}$ \\
\hline
\end{tabular}

Source: Author Data Process (2020)

$\mathrm{Eq} 2: \mathrm{BA}=0,348 \mathrm{BE}+0,608 \mathrm{CS}$

The results indicate that brand experience has the greatest effect on customer satisfaction rather than perceived quality and brand trust. This means that the level of customer satisfaction on the KAI Access application is based on previous experience using the KAI Access application. If users feel that KAI Access application provides more benefits than similar applications, customer satisfaction will be higher, so 
they make repeated purchases in the future and vice versa. Meanwhile, the brand awareness of customer satisfaction and brand experience variables find that the greatest effect is customer satisfaction. This means that brand awareness is established from customer satisfaction, while customer satisfaction is built from brand experience from repeated consumption that is not just one time.

\section{CONCLUSIONS}

The research is conducted to determine the level of relationship between variables of brand experience, perceived quality, brand trust, customer satisfaction and brand awareness. It can be concluded that: 1) brand experience and perceived quality have positive effects on customer satisfaction; 2) brand trust does not have positive effects on customer satisfaction; 3 ) customer satisfaction and brand experience have positive effects on brand awareness.

Companies engaged in trust services have an important role in selecting a brand that will be used by customers. However, if the company is a monopoly company, consumers will have no choice but to follow the policies and rules of the brand owner. To increase customer satisfaction, companies should form a pleasant experience of using so that satisfaction and a good perception of a brand arise. A good brand will establish awareness that customers remember to make purchases in the future.

Further studies are suggested to expand the respondents (all KAI Access users, not just millennials) as well as new respondents to determine the reasons for choosing KAI Access, to expand the research coverage area to Divre in Sumatra. Besides, future research may also add measurement variables about customer satisfaction and brand awareness. The results have limitations, namely: (1) respondents are only those who have used the KAI Access application before, from millennials only, even though generation $\mathrm{Z}$ has started to enter the workforce; (2) questionnaires and statements are further expanded, thereby reducing the level of the subjectivity of respondents; (3) studied variables are only those that have the brand experience, perceived quality and brand trust, customer satisfaction and brand awareness.

The managerial implication that can be done is in terms of marketing strategies that need to be addressed regarding the distribution of sub-class ticket prices in KAI Access so that the cheapest ticket prices in the sub-class are only sold on KAI Access. It is expected that users mindset will be formed that KAI Access has the cheapest price than other similar applications. Moreover, it is essential to: 1) provide points, member points, price discounts, and integrated merchant discounts that are attractive to new and loyal KAI Access customers; 2) add options for payment and refund methods such as using other e-wallets (Gopay, OVO, and DANA); 3) add technicians or customer service training on stations so that they can solve problems (i.e., the KAI Access application is not synchronized with the Link application); 4) improve differentiating services between passengers using e-boarding passes and manual boarding passes, for example implementing an e-gate system (self-check-in) for passengers using KAI Access; 5) expand promotional media by using media outside of KAI, whose system is simple, easy-to-use, and straightforward so that it is easier for consumers to update and change their account data; 6) protect the confidentiality of consumer personal data from theft and illegal trade; 7) provide a more practical and fast solution to fraud and failure of the KAI Access and Link Aja payment systems so that it does not harm consumers.

\section{REFERENCES}

Aaker, D. A. (1991). Managing brand equity: Capitalizing on the value of a brand name. The Free Press.

Acebrón, L. B. \& Dopico, D. C. The importance of intrinsic and extrinsic cues to expected and experienced quality: An empirical application for beef. Food Quality and Preference, 11(3), 229-238. https://doi. org/10.1016/S0950-3293(99)00059-2.

Agata, R. P, Djawahir, A. H., \& Andarwati (2017). Pengaruh brand experience terhadap brand satisfaction, brand trust dan brand loyalty (Studi pada konsumen makeup brand impor di Surabaya). Jurnal Manajemen Fakultas Ekonomi dan Bisnis Universitas Merdeka Malang, 5(2). https://doi.org/10.26905/jmdk. v5i2.1355.

Ardyan, E., Kurnianingsih, H., Rahmawan, G., Wibisono, U., \& Winata. (2016). Enhancing brand experience along with emotional attachment towards trust and brand loyalty. Jurnal Manajemen dan Kewirausahaan, 18(1), 33-44. https://doi.org/10.9744/jmk.18.1.3344.

Badan Pusat Statistik (BPS). (2019). Statistik E-commerce 2019. Katalog BPS:8101004. ISBN:978-602438-290-2., Catalog:81(06320.1902). https:// www.bps.go.id/publication/2019/12/18/ fd 1 e 96 b05342e479a83917c6/statistik-ecommerce-2019.html.

Başer, İ. U., Cintamür, İ. G., \& Arslan, F. M. (2016). Examining the effect of brand experience on consumer satisfaction, brand trust and brand loyalty. İktisadi ve Idari Bilimler Dergisi, 37(2), 101. https:// doi.org/10.14780/iibd.51125.

Baumann, C., Hamin, H., \& Chong, A. (2015). The role of brand exposure and experience on brand recallProduct durables vis-à-vis FMCG. Journal of Retailing and Consumer Services, 23, 21-31. https:// doi.org/10.1016/j.jretconser.2014.11.003.

Brakus, J. J., Schmitt, B. H., \& Zarantonello, L. (2009). Brand experience: What is it? How is it measured? Does it affect loyalty? Journal of Marketing, 52-68. https://doi.org/10.1509/jmkg.73.3.052.

Bilgili, B. \& Ozkul, E. (2015). Brand awareness, brand personality, brand loyalty and consumer satisfaction 
relations in brand positioning strategies (A Torku brand sample). Journal of Global Strategic Management, 9(2), 89-106. https://doi.org/10.20460/ JGSM.2015915576.

Carrizo-Moreira, A., Freitas-da Silva, P. M. \& FerreiraMoutinho, V. M. (2016). The effects of brand experiences on quality, satisfaction and loyalty: An empirical study in the telecommunications multipleplay service market. Innovar, 27(64), 23. http:// dx.doi.org/10.15446/innovar.v27n64.62366.

Chinomona, R. (2013). The influence of brand experience on brand satisfaction, trust and attachment in South Africa. International Business \& Economics Research Journal, 12(10), 1303-1316. https://doi. org/10.19030/iber.v12i10.8138.

Cleff, T., Lin, I. C., \& Walter, N. (2014). Can you feel it? - The effect of brand experience on brand equity. The IUP Journal of Brand Management, 11(2), 7-27. https://www.researchgate.net/ publication/263470342_Can_You_Feel_It_The Effect_of_Brand_Experience_on_Brand_Equity.

Cordasco, M. (2016, April 12). 4 reasons why people aren't using your mobile app. MyCrowd. https://mycrowd. com/blog/4-reasons-why-people-arent-using-yourmobile-app/.

Durianto, D., Sugiarto, \& Sitinjak, T. (2001). Strategi Menaklukkan Pasar Melalui Riset Ekuitas dan Perilaku Merek. Jakarta: PT Gramedia Pustaka Utama.

East, R. (1997). Consumer Behaviour: Advances and Applications in Marketing ( $1^{\text {st }}$ Ed.). London: Prentice-Hall.

East, R., Jaywant S., Malcolm W., \& Marc V. (2016). Consumer behaviour: Applications in Marketing. SAGE.

Engel, F., James, Blackwell, D., Roger, \& Minard, B. P. (2010). Perilaku Konsumen Jilid I (Keenam). Binarupa Aksara.

Firmansyah, A. (2019). Pemasaran Produk dan Merek: Planning dan Strategy. Penerbit Qiara Media ISBN 6237365095, 9786237365099.

Ghozali, I. (2013). Aplikasi Analisis Multivariate dengan Program IBM SPSS 21 Update PLS Regresi. Badan Penerbit Universitas Diponegoro.

Howe, N., \& Strauss, W. (2000). Millennials rising: The Next Great Generation. Knopf Doubleday Publishing Group.

Irawan, H. (2012, March 12). Karakter dan perilaku khas konsumen Indonesia. Marketing.co.id http:// marketing.co.id/karakter-dan-perilaku-khaskonsumen-indonesia/.

Kiyani, T., Niazi, M. R., \& Niazi, R. A. (2012). The relationship between brand trust, customer satisfaction, and customer loyalty: Evidence from automobile sector of Pakistan. Interdisclipinary Journal of Contemporary Research In Business, 4(1), 489-502. https://journal-archieves18.webs. com/489-502.pdf.

Milenial lebih prioritaskan liburan dibanding beli rumah. (2017, October 12). Kompas.com. https://biz. kompas.com/read/2017/10/12/084045628/milenial- lebih-prioritaskan-liburan-dibanding-beli-rumah

KAI Access train booking, reschedule, cancellation. (2019, September 28). PlayStore Review. https:// play.google.com/store/apps/details?id=com.kai. kaiticketing\&hl=in.

Kotler, P. \& Kevin, L. K. (2015). Marketing Management $\left(15^{\text {th }}\right.$ Ed.). Pearson Pretice Hall, Inc.

Larasati, D. A., Az-Zahra, H. M., \& Dewi, R. K. (2018). Evaluasi user experience dengan mengadaptasi meCUE Questionnaire pada aplikasi KAI Access dan aplikasi Tiket.com. Jurnal Pengembangan Teknologi Informasi dan Ilmu Komputer, 2(12), 6661-6668. http://repository.ub.ac.id/id/eprint/161947.

Liao, S. H, Y. C. Chung, Y. R. H. \& R. W. (2015). The Impact of brand trust, Costumer satisfaction anf brand loyalty on word of mouth. Proceedings of the 2010 International Conference on Industrial Engineering and Engineering Management Uploaded 2015. https://doi.org/10.1109/IEEM.2010.5674402.

Lin, H-H. \& Wang, Y-S. (2006). An examination of the determinants of customer loyalty in mobile commerce contexts. Information \& Management, 43(3), 271282. https://doi.org/10.1016/j.im.2005.08.001

Minta, Y. (2018). Link between satisfaction and customer loyalty in insurance industry: Moderating effect of trust and commitment. Journal of Marketing Management, 6(2), 25-33. http://jmm-net.com/ journals/jmm/Vol_6_No_2_December_2018/3.pdf.

Nair, S. (2013). Assessing customer satisfaction and brand awareness of branded bread. IOSR Journal of Business and Management, 12(2), 13-18. https://doi. org/10.9790/487X-1221318.

Nobar, H. B. \& Rostamzadeh R. (2018). The impact of customer satisfaction, customer experience and customer loyalty on brand power: Empirical evidence from hotel industry. Journal of Business Economics and Management, 19(2), 417-430. https://doi.org/10.3846/jbem.2018.5678.

Parry, E. \& Urwin, P. (2011). Generational differences in work values: A review of theory and evidence. Internaional Journal of Management Reviews, 13(1), 79-96. https://doi.org/10.1111/j.14682370.2010.00285.x

Saleem, A., Ghafar, A., Ibrahim, M., Yousuf, M., \& Ahmad, N. (2015). Product perceived quality and purchase intention with consumer satisfaction. Global Journal of Management and Business Research, 15(1-E). https://journalofbusiness.org/index.php/GJMBR/ article/view/1684.

Sekaran, U. \& Bougie, R. (2010). Research Method for Business: A Skill Building Approach ( $5^{\text {th }}$ Ed.). New York: John Wiley \& Sons.

Saputra, R. \& Dewi, C. K. (2016). The impact of brand trust on brand loyalty mediated by customer satisfaction: Case of Tokobagus.com (now OLX.co.id). Journal of Administrative and Business Studies, 1(1), 8-13. https://doi.org/10.20474/jabs-1.1.2.

Setyawan, A. A, Kussdiyarsana, \& Imronudin. (2015). Brand trust and brand loyalty, an empirical study in Indonesia consumers. Journal of Marketing Studies, 4(3), 37-47. https://www.researchgate. 
net/publication/303302646_brand_trust_and brand_loyalty_an_empirical_study_in_indonesia_ consumers.

Sidabutar, C. B. \& Diah D. (2015). Analisa pengaruh brand experience terhadap customer loyalty melalui brand trust, customer satisfaction dan customer intimacy sebagai variabel intervening pada Kiehl's Surabaya. Jurnal Manajemen Pemasaran Petra, 1(1), 1-10. http://studentjournal.petra.ac.id/index. php/manajemen-pemasaran/article/view/3946/3605.

Souki, G. Q. \& Filho, C. G. (2008). Perceived quality, satisfaction and customer loyalty: An empirical study in the mobile phones sector in Brazil. International Journal of Internet and Enterprise Management, 5(4), 298-312. https://doi.org/10.1504/ IJIEM.2008.020103.

Spais, G. S. \& Vasileiou, K. (2006). Path modeling the antecedent factors to consumer repurchase intentions for advanced technological food products:
Some correlations between selected factor variables. Journal of Business Case Studies, 2(2), 45-72. https://doi.org/10.19030/jbcs.v2i2.4889.

Sugiyono. (2008). Metode Penelitian Pendidikan Pendekatan Kuantitatif, Kualitatif, dan $R \& D$. Alfabeta.

Widowati, H. (2019, April 25). Indonesia jadi negara dengan pertumbuhan e-commerce tercepat di dunia. Databoks. https://databoks.katadata.co.id/ datapublish/2019/04/25/indonesia-jadi-negaradengan-pertumbuhan-e-commerce-tercepat-didunia.

Xixiang, S., Gilal, R. G., \& Gilal, F. G. (2016). Brand experience as a contemporary source of brand equity in 21 st Century: Evidence from the Chinese consumer market. International Journal of Education and Research, 4(9). 63-76. http://w.ijern. com/journal/2016/September-2016/06.pdf. 